\title{
Performance Evaluation of Tractor Operated Fertilizer Broadcaster
}

\author{
Satish Manda ${ }^{1 *}$, Arpit Kumar ${ }^{1}$ and S. Mukesh ${ }^{2}$ \\ ${ }^{1}$ Department of Agricultural and Food Engineering, Indian Institute of Technology \\ Kharagpur, India \\ ${ }^{2}$ Department of Farm Machinery and Power Engineering, CCS Haryana Agricultural \\ University, Hisar, India \\ *Corresponding author
}

\section{A B S T R A C T}

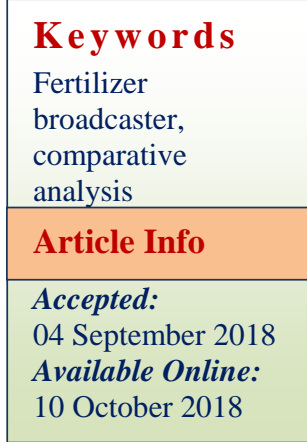

\section{Introduction}

The northern part of India has high cropping intensity, states like Punjab and Haryana have cropping intensity of $194.3 \%$ and $169.0 \%$. Thus, the number of crops grown on the same fields leads to nutrient deficiency in the soil. As nutrients available in the soil plays significant role in the growth of plant and affect the crop yield. To provide the nutrients in the soil generally fertilizers are applied to soil. In the large part of the country farmers generally apply the fertilizer manually which lead to non-uniform application of the fertilizer and the process is laborious. Thus, to make fertilizer application more uniform and

\begin{abstract}
The performance of tractor operated fertilizer broadcaster was evaluated at RDS farm, CCS Haryana Agricultural University, Hisar, Haryana in Rabi, 2014. Fertilizers are uniform application in the field. Thus performance of the fertilizer broadcaster was evaluated in the field to check its applicability to overcome above mentioned problem of non-uniform application. The comparative analysis of the performance of conical fertilizer broadcaster and square fertilizer was also performed. The actual field capacity was

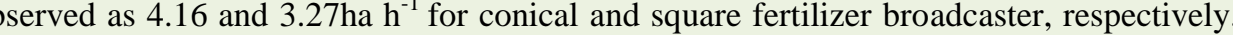
The field efficiency calculated was 60.1 and $79.0 \%$ for conical and square fertilizer broadcaster respectively when tested in levelled field.
\end{abstract}

efficient fertilizer broadcasters can be used. Fertilizer broadcaster is an equipment which is designed particularly to spread fertilizer with great ease and efficiency. As mentioned earlier manual broadcasting of fertilizer is more laborious, time consuming and health hazardous. This machine is comfortable to use, less time consuming and does not cause any health hazard to the farmers. It can spread fertilizer over 12 to $14 \mathrm{~m}$ width in the field. Its unique distributing mechanism ensures uniform spreading of fertilizer over a large area. There is provision in the machine to adjust the quantity of the fertilizer to be broadcasted as per the requirement by adjusting the levers provided. 
Different types of fertilizer broadcaster are available for the use, but they differ in the type of hopper and distributor used for spreading the fertilizer.

\section{Materials and Methods}

Fertilizer broadcaster is an equipment with three point linkage operated with tractor Power Take Off (PTO) shaft. Tests were performed on the machines to evaluate their performance. Two types of fertilizer broadcasters i.e. conical type and square type were evaluated for their performance. Conicaltype fertilizer broadcaster have its hopper in the shape of cone. The calibration was performed in the laboratory of Department of Farm Machinery and Power Engineering, CCS Haryana Agricultural University, Hisar. The dimensions and other details of conical fertilizer broadcaster are shown in Table 1. Apertures are provided at the bottom of the hopper with the sliding shutter. The sliding shutter is adjusted with a lever which is mounted on an indexing plate which have holes provided for adjustment.

The dimensions and other details of square fertilizer broadcaster are shown in Table 2. Its capacity is less than conical type. It has more number of aperture compared to the conical fertilizer broadcaster.

\section{Field test}

To evaluate the performance of fertilizer broadcaster, tests were conducted at RDS Farm, CCSHAU, Hisar, Haryana. Test was performed for 20 hours in number of trials. Fertilizer used for the test was DAP. Tractor operator is the only labour required to operate the machine. During each trail, the data related to performance of the machines was collected that includes total fertilizer spread, fertilizer application rate by changing the operating parameters such as speed of the tractor, PTO
RPM, aperture opening and angle of blade of distributor. The effect of operating parameter was analyzed and performance of machine was determined in terms of uniformity coefficient, actual field capacity, field efficiency and fuel consumption.

\section{Comparative analysis}

The performance of the conical and square fertilizer was compared at the same operating condition. The effect of the change of angle of blade on the spreading width was analyzed. A comparative analysis was performed for the two machine on the parameters such as field capacity, field efficiency and fuel consumption.

\section{Results and Discussion}

\section{Conical fertilizer broadcaster}

The effect of operational parameters on the performance was analyzed and observed that with the change in the forward speed from 4.23 to $4.76 \mathrm{kmph}$ the uniformity coefficient which shows the evenness of spreading of fertilizer varied from 53.8 to 56.7.The maximum uniformity coefficient was observed at the speed of $4.25 \mathrm{kmph}$, and with further increase in speed it decreased. The fertilizer application rate was in the range of 114 to 125 $\mathrm{kg} / \mathrm{ha}$ and corresponding fuel consumption varied from $3.22 \mathrm{l} / \mathrm{h}$ to $3.75 \mathrm{l} / \mathrm{h}$. The results obtained from the different trials are shown in the Table 3.

\section{Square fertilize broadcaster}

The effect of operational parameters on the performance was analyzed and observed that with the change in the forward speed from 3.03 to $3.12 \mathrm{kmph}$ the uniformity coefficient varied from 54.6 to 59.2. The maximum uniformity coefficient was observed at the speed of $3.05 \mathrm{kmph}$. 
Table.1 Constructional details of conical fertilizer broadcaster

\begin{tabular}{|l|l|l|}
\hline S. no & Particulars & Specification \\
\hline 1. & Hopper & \\
Diameter of hopper at top, $\mathrm{mm}$ & 1145 \\
\hline & Diameter of hopper at bottom, $\mathrm{mm}$ & 146 \\
\hline & Height of hopper, $\mathrm{mm}$ & 905 \\
\hline $\begin{array}{l}\text { Capacity } \\
\text { Metering mechanism }\end{array}$ & $450 \mathrm{~kg}$ \\
\hline F. & Apertures are provided at the bottom \\
\hline & Number of apertures & 2 \\
\hline Controller & Indexing lever with plate \\
\hline Number of holes on indexing plate & 8 \\
\hline Dimension of aperture, mm & $117 \times 72$ \\
\hline Fertilizer distributor & \\
\hline Number of disc & 1 \\
\hline Diameter of Disc, $\mathrm{mm}$ & 450 \\
\hline Number of distributor vane & 4 \\
\hline Length of blade, $\mathrm{mm}$ & 180 \\
\hline Height of blade, $\mathrm{mm}$ & 50 \\
\hline Angles of blades, degrees & $0^{\circ}, 21^{\circ}, 47^{\circ}, 60^{\circ}$ \\
\hline
\end{tabular}

Table.2 Constructional details of square fertilizer broadcaster

\begin{tabular}{|c|c|c|}
\hline S. no & Particulars & Specification \\
\hline \multirow[t]{5}{*}{1.} & Hopper & \\
\hline & Size of hopper at top, $\mathrm{mm}$ & $1000 \times 1000$ \\
\hline & Size of hopper at bottom, $\mathrm{mm}$ & $180 \times 180$ \\
\hline & Height of hopper, mm & 860 \\
\hline & Capacity, kg & 400 \\
\hline \multirow[t]{6}{*}{2.} & Metering mechanism & \\
\hline & Feeder & Apertures are provided at the bottom \\
\hline & Number of apertures & 3 \\
\hline & Controller & Indexing lever with plate \\
\hline & Number of holes on indexing plate & 8 \\
\hline & Dimension of aperture, $\mathrm{mm}$ & $54 \times 48$ \\
\hline \multirow[t]{7}{*}{3.} & Fertilizer distributor & \\
\hline & Number of disc & 1 \\
\hline & Diameter of Disc, $\mathrm{mm}$ & 432 \\
\hline & Number of distributor vane & 4 \\
\hline & Length of blade, $\mathrm{mm}$ & 190 \\
\hline & Height of blade, $\mathrm{mm}$ & 30 \\
\hline & Angles of blades, degrees & $0^{\circ}, 22^{\circ}, 33^{\circ}, 44^{\circ}$ \\
\hline
\end{tabular}


Table.3 Effect of change in operational parameter on performance of conical type Fertilizer broadcaster

\begin{tabular}{|c|c|c|c|c|c|c|c|c|c|}
\hline Test & $\begin{array}{c}\text { Duration, } \\
\text { h }\end{array}$ & $\begin{array}{c}\text { Speed of } \\
\text { tractor, } \\
\mathrm{Km} / \mathrm{h}\end{array}$ & $\begin{array}{c}\text { Angle of } \\
\text { blades of } \\
\text { distributor } \\
\text { plate }\end{array}$ & \begin{tabular}{|c|} 
Total \\
fertilizer \\
spreading \\
width, m
\end{tabular} & $\begin{array}{c}\text { Fertilizer } \\
\text { application } \\
\text { rate, kg/ha }\end{array}$ & $\begin{array}{l}\text { Uniformity } \\
\text { coefficient }\end{array}$ & $\begin{array}{c}\text { Actual } \\
\text { field } \\
\text { capacity, } \\
\text { ha/h }\end{array}$ & $\begin{array}{c}\text { Field } \\
\text { efficiency, } \\
\%\end{array}$ & $\begin{array}{c}\text { Fuel } \\
\text { consumption } \\
\text { l/h }\end{array}$ \\
\hline 1 & 3.5 & 4.25 & $21^{\circ}$ & 13.2 & 125 & 56.7 & 3.68 & 65.6 & 3.75 \\
\hline 2 & 4.5 & 4.68 & $21^{\circ}$ & 13.0 & 118 & 55.4 & 3.70 & 60.9 & 3.56 \\
\hline 3 & 4.0 & 4.76 & $47^{\circ}$ & 16.8 & 114 & 53.8 & 4.62 & 57.8 & 3.22 \\
\hline 4 & 3.5 & 4.23 & $47^{\circ}$ & 16.6 & 125 & 56.4 & 4.08 & 58.1 & 3.86 \\
\hline 5 & 4.5 & 4.56 & $60^{\circ}$ & 17.8 & 120 & 55.6 & 4.72 & 58.2 & 3.76 \\
\hline
\end{tabular}

Table.4 Effect of change in operational parameter on performance of square type Fertilizer broadcaster

\begin{tabular}{|c|c|c|c|c|c|c|c|c|c|}
\hline Test & $\begin{array}{c}\text { Duration, } \\
\mathbf{h}\end{array}$ & $\begin{array}{c}\text { Speed of } \\
\text { tractor, } \\
\mathrm{Km} / \mathrm{h}\end{array}$ & $\begin{array}{c}\text { Angle of } \\
\text { blades of } \\
\text { distributor } \\
\text { plate }\end{array}$ & $\begin{array}{c}\text { Total } \\
\text { fertilizer } \\
\text { spreading } \\
\text { width, m }\end{array}$ & $\begin{array}{c}\text { Fertilizer } \\
\text { applicati } \\
\text { on rate, } \\
\text { kg/ha }\end{array}$ & $\begin{array}{l}\text { Uniformity } \\
\text { coefficient }\end{array}$ & $\begin{array}{c}\text { Actual } \\
\text { field } \\
\text { capacity, } \\
\text { ha/h }\end{array}$ & $\begin{array}{c}\text { Field } \\
\text { efficiency, } \\
\%\end{array}$ & $\begin{array}{c}\text { Fuel } \\
\text { consu } \\
\text { mption } \\
\text { //h }\end{array}$ \\
\hline 1 & 4.0 & 3.05 & $22^{\circ}$ & 13.83 & 119 & 59.2 & 3.46 & 81.97 & 3.69 \\
\hline 2 & 3.5 & 3.03 & $22^{\circ}$ & 13.80 & 114 & 58.5 & 3.21 & 78.20 & 3.64 \\
\hline 3 & 4.5 & 3.09 & $22^{\circ}$ & 13.78 & 109 & 54.6 & 3.16 & 77.34 & 3.38 \\
\hline 4 & 8.0 & 3.12 & $22^{\circ}$ & 13.91 & 120 & 58.4 & 3.28 & 78.52 & 3.17 \\
\hline
\end{tabular}

Table.5 Comparative performance of fertilizer broadcasters

\begin{tabular}{|l|l|}
\hline S. no & P. \\
\hline 1. & . \\
\hline 2. \\
\hline 3. \\
\hline 4. \\
\hline 5. \\
\hline 6. \\
\hline 7. \\
\hline 8. \\
\hline 9. \\
\hline 10 \\
\hline
\end{tabular}

\section{Parameters}

Field condition

Speed of operation, $\mathrm{km} / \mathrm{h}$

Total fertilizer spreading width, $\mathrm{m}$

Fertilizer application rate, $\mathrm{kg} / \mathrm{ha}$

Uniformity coefficient

Actual field Capacity, ha/h

Field efficiency, $\%$

Fuel consumption, $1 / \mathrm{h}$

Fuel consumption, 1/ha

PTO power requirement, hp

\begin{tabular}{|l|l|}
\hline Square type & Conical type \\
\hline Levelled field & Levelled field \\
\hline 3.03 to 3.12 & $4.23-4.76$ \\
\hline 13.78 to 13.91 & $13.0-17.8$ \\
\hline 109 to 120 & 114 to 125 \\
\hline 54.6 to 59.2 & 53.8 to 56.7 \\
\hline 3.16 to 3.46 & 3.68 to 4.72 \\
\hline 77.34 to 81.97 & 57.8 to 65.6 \\
\hline 3.17 to 3.69 & 3.56 to 3.88 \\
\hline 0.97 to 1.13 & 0.80 to 1.02 \\
\hline 5.8 to 6.4 & 6.2 to 6.7 \\
\hline
\end{tabular}


The fertilizer application rate was in the range of 109 to $120 \mathrm{~kg} / \mathrm{ha}$ and corresponding fuel consumption varied from $3.17 \mathrm{l} / \mathrm{h}$ to $3.69 \mathrm{l} / \mathrm{h}$. The results obtained from the different trials are shown in the Table 4.

\section{Comparative analysis}

The performance of conical and square fertilizer broadcaster was analyzed for various parameters. The results are shown in Table 5.

In this study the performance of two types of fertilizer broadcaster was analyzed. Based on the study it can be concluded that fertilizer broadcaster enhanced the fertilizer application as it is convenient to use and efficient. Both square type and conical type fertilizer broadcasters performed satisfactory in the levelled field. The field efficiency for square type fertilizer broadcaster was $81.97 \%$ which was higher compared to conical type $65.6 \%$. The maximum field capacity was more for the conical type $4.72 \mathrm{ha} / \mathrm{has}$ compared to $3.46 \mathrm{ha} / \mathrm{h}$ of square type. Thus, these broadcasters can be used in the levelled field for fertilizer application.

\section{References}

Abraham, Arun, Balan, Arjun S., Aravind, M G. and Akhil P.T. 2017. Design and fabrication of trolley mounted fertilizer spreader. International Journal for
Innovative Research in Science \& Technology, 3(11): 2349-6010.

Amerine, J. D. and R. L. Parish. Development of a rotary spreader with an elliptical shroud. ASAE paper number 79-1511.

Cunningham F M; Chao, E Y S. 1967. Design relationships for centrifugal fertilizer distributors. Transactions of the ASAE, 10(1), 91-95.

Narode, R., Sonawane, A., Mahale, R., Nisal, S., Chaudhari, S. and Bhane, A. Manually operated fertilizer spreader. ISSN 2250-2459, ISO 9001:2008 Certified Journal, Volume 5, Issue 2, February 2015.

Patterson D E., Reece A R. The theory of the centrifugal distributor. I: Motion on the disc, near center feed. Journal of Agricultural Engineering Research, 7(3), 232-240.

Sharma D. S. and S. Mukesh, Farm Machinery Design Principles and problems, PP- 225-245.

Vangeyte, J., Sonck, B., Van Liedekerke, P., Ramon, H. Comparison of two methods to measure the outlet velocity of fertiliser grains from a rotary disc. In: Proceedings of AgEng 2004, Leuven, Belgium, 12-16 September 2004.

Vignesh, B., Navaneetha, Krishnan, M. and Sethuraman, N. 2017. Design \& Fabrication of Automatic Fertilizer Spreader. International Journal for Scientific Research \& Development|, Vol. 5, Issue 04: 2321-0613.

\section{How to cite this article:}

Satish Manda, Arpit Kumar and Mukesh, S. 2018. Performance Evaluation of Tractor Operated Fertilizer Broadcaster. Int.J.Curr.Microbiol.App.Sci. 7(10): 25-29. doi: https://doi.org/10.20546/ijcmas.2018.710.004 